\author{
Ludmila STEPASYUK ${ }^{1}$ \\ Zoia TITENKO ${ }^{2}$
}

\title{
FINANCIAL AND ORGANIZATIONAL IMPLEMENTATION OF STATE SUPPORT FOR LIVESTOCK PRODUCERS
}

\begin{abstract}
The article is devoted to the study of the state financial support to the livestock industry, which occupies a strategically important niche in the overall structure of agricultural production. The peculiarities and problems of providing financial support to livestock producers are analyzed. It has been proven that effective public financial support for the livestock industry should be based on well-defined strategic goals and development indicators that will capture new markets for livestock products and help improve the competitiveness of products. The article emphasizes that the initial priorities of the state support of animal husbandry of Ukraine are: improvement of the financial and credit and investment policy of the state in the issues of accelerated increase of livestock of cattle and production of quality products by agricultural enterprises.

The purpose of the article is to analyze the state of financial support for the livestock industry and to substantiate measures for its improvement.
\end{abstract}

Keywords: animal husbandry, government support, agricultural production, budgetary funds, the agricultural sector of the economy.

\section{INTRODUCTION}

In solving the problem of food supply to the population, a special role belongs to the livestock industry, as the main supplier of products - sources of proteins of animal origin. Instead, the domestic livestock industry is in a dispersive state, which gives reason to speak not of its development but a revival, as a priority task of the macroeconomic agrarian policy of the state (Yemtsev, 2012).

Effective development of the livestock industry contributes to the strategically important tasks, including a secured supply of the population with quality food; improving life in rural areas and income citizens; curbing the negative tendencies of rural depopulation; ensuring the development of rural social infrastructure. Given the

\footnotetext{
${ }^{1}$ Ludmila Stepasyuk, PhD in Economics, Associate professor of the Department of Economics of Enterprise, National University of Life and Environmental Sciences of Ukraine; e-mail:ludastepasuk@gmail.com. ORCID: 0000-0002-4820-9132.

${ }^{2}$ Zoia Titenko, PhD in Economics, Associate professor of the Department of Finance, National University of Life and Environmental Sciences of Ukraine; e-mail:zoyateslenko@ukr.net (corresponding author). ORCID: 0000-0001-5816-5519.
} 
importance of the industry, it must be closely monitored by the state, since it requires operational state support, the extent of which depends on the current situation in the industry.

First of all, it is important to understand what is hindering the development of animal husbandry in Ukraine, which, by the way, is more than $38 \%$ in the structure of gross agricultural production. One of the main factors that have the negative impact on its development is the lack of stability and state support for agricultural producers, unpredictable pricing policies, low export potential and, as a consequence, the absence of markets. All this hurts the industry. Foreign investors are afraid to invest their funds given the volatile economic and political situation in the country. If poultry and pig breeding are more or less attractive for investment because of the specific nature of production, because in a relatively short time it is possible not only to return the money invested but also to make a profit, then the development of animal husbandry requires additional government intervention. Experts and even the manufacturers themselves understand that it takes a long time to repay the investment, not to mention the extra profit (6-7 years). And in an unstable economic situation, it is quite risky.

In recent years, agro holdings have been developing at a faster rate as they have the financial and technical capacity to implement modern technologies and produce quality products. And although cattle numbers are steadily declining, livestock productivity is increasing. However, at present the state has decided to take seriously the revival of livestock breeding and is beginning to take slow steps to increase livestock (Synyavina, 2015).

\section{LITERATURE REVIEW}

The problem of state support for agriculture and identifying ways to improve its efficiency has always been urgent. Therefore, a considerable number of works of leading domestic agrarian economists are devoted to the issues of state financial support for agriculture and in particular animal husbandry, among them P.I. Haydutsky (Haydutsky, 2017), O.M. Galitsky (Galitsky, 2016), R.E. Demchak (Demchak, 2015), S.O. Kushnir (Kushnir, 2017), Yu.O. Lupenko (Lupenko, Tulush, 2016), V.Ya. Mesel-Veselyak (Mesel-Veselyak, Fedorov, 2016), O.V. Panuhnik (Panukhnik, 2017), L.D. Tulush (Tulush, 2017) and Yu.O. Ulyanchenko (Ulyanchenko, 2013). However, the current state of the livestock industry and aspects of its state support need constant monitoring to make decisions about its effectiveness.

The study found that legal and economic research conducted by foreign and domestic scientists over a long period reaffirmed the need for state support for the agrarian sector of the economy to ensure the economic security of the state and the effective development of agriculture.

\section{METHODOLOGY}

The methodological basis of the study is a systematic approach to defining the fundamental provisions of the theory of state financial support for animal husbandry, as a strategically important field of agricultural production. In the course of the research, a suitable complex of methods was used: dialectical and abstract - logical (for theoretical generalization and formulation of conclusions), economic-statistical (for characterizing the current state of the industry), monographic (for illuminating the views of scientists on 
problems and categories), economic-statistical (for a comprehensive assessment of financial support for the livestock industry ) and graphical method.

\section{CASE STUDIES}

Government support for the livestock sector is the lion's share of the total support. The total budget for this program is 4 billion $\mathrm{UAH}$.

Budget funds are allocated for state support in the following areas:

1) partial compensation of interest rate on bank loans involved to cover the costs associated with the activities in the fields of sheep, goat, beekeeping, fur farming, rabbit breeding, silkworms, and aquaculture - partial compensation of interest rates on bank loans and interest paid in the current year amounting to 1.5 of the National Bank discount rate);

2) partial compensation for the cost of construction and reconstruction of livestock farms and complexes, milking parlors, agricultural processing enterprises in terms of costs financed by bank loans (the amount of compensation $-25 \%$ of the loan body);

3 ) a special budget grant for keeping cows of dairy, dairy and meat and meet direction;

The grant is provided on a non-refundable basis twice a year to economic entities that are legal entities for each available identified and registered cow as of January 1 and July 1 of the current year in the amount of $750 \mathrm{UAH}$ per head.

4) special budget subsidy for rearing cattle born in the farms of individuals given to individuals every four months keeping young cattle for age young to 13 months of age up to 2.5 thousand. UAH per head young in ;

5) partial reimbursement of the value purchased for further reproduction of breeding animals, namely heifers, calf, dairy cows, dairy and meat products, female pigs and male pigs, ewes, rams, boars and cattle and embryos of cattle and embryos having a breeding (genetic) value;

6) partial reimbursement of the cost of construction and reconstruction of livestock farms and complexes, milking parlors, agricultural processing enterprises (Resolution of the Cabinet of Ministers of Ukraine, 2018).

Partial reimbursement of the objects is provided to the entities on a non-refundable basis in the amount of 30 percent of the value of the object up to 500 million UAH of the total value of such object (excluding value-added tax), completed in the current year stages of construction and reconstruction of livestock farms and complexes for cattle, pigs, poultry (including waterfowl and turkeys), milking parlors, agricultural processing enterprises (milk, meat, animal by-products spare belonging to Category II), including the cost of equipment in accordance with the design and estimate documentation, and for objects with a higher cost - 30 percent of the 500 million UAH.

To support the development of livestock industries in 2018. from the general fund of the state budget was provided appropriations in the amount of 2401 million UAH. But actually directed recipients 2389844 thous., i.e,approximate remains of unused funds amounted to -11156 thousand UAH, or less than $0.5 \%$. It should be noted, that the highest percentage of not used funds and is $3.2 \%$ reached in the program „Compensation cost facilities, financed by funds of bank loans" (Table 1). 
Table 1. State of disbursement of funds of the General Fund of the state budget provided for supporting the development of livestock industries, 2018

\begin{tabular}{|l|c|c|c|c|}
\hline \multicolumn{1}{|c|}{ Program / direction } & \multirow{2}{*}{$\begin{array}{c}\text { Plan allocati } \\
\text { ons for } \\
\text { 2018 year }\end{array}$} & \multicolumn{2}{|c|}{$\begin{array}{c}\text { Adopted decisions regarding } \\
\text { payments support }\end{array}$} & \multicolumn{1}{c|}{ The } \\
\cline { 3 - 4 } & Total & $\begin{array}{c}\text { It is actually } \\
\text { aimed at the } \\
\text { recipients } \\
\text { used funds }\end{array}$ & \\
\hline $\begin{array}{l}\text { State support to the livestock } \\
\text { sector, incl }\end{array}$ & 2401000 & 2393294,8 & 2389844,2 & 11155,8 \\
\hline $\begin{array}{l}\text { Partial offsetting of interest } \\
\text { rates on bank loans }\end{array}$ & 4000,00 & 3747,70 & 3747,70 & 252,3 \\
\hline $\begin{array}{l}\text { Compensation cost of facili- } \\
\text { ties, financed by funds of bank } \\
\text { loans }\end{array}$ & 65000,00 & 62926,10 & 62926,10 & 2073,90 \\
\hline $\begin{array}{l}\text { Special budget subsidy for kee } \\
\text { ping cows }\end{array}$ & 515000,0 & 514503,8 & 511836,6 & 3163,4 \\
\hline $\begin{array}{l}\text { Special budgetary subsidies for } \\
\text { cultivation of young great } \\
\text { horned cattle }\end{array}$ & 322000,0 & 320864,9 & 320081,4 & 1918,6 \\
\hline $\begin{array}{l}\text { Partial reimbursement of value } \\
\text { purchased for further reproduct } \\
\text { ion of breeding animals }\end{array}$ & 215000,0 & 214572,5 & 214572,5 & 427,5 \\
\hline $\begin{array}{l}\text { Partial reimbursement } \\
\text { of objects }\end{array}$ & 1280000,00 & 1276679,9 & 1276679,9 & 3320,1 \\
\hline
\end{tabular}

In the structure of expenditures on state support for the development of livestock and the highest share occupied expenditure for partial reimbursement of the cost of objects of fixed assets, and it is $-53.4 \%$, that amounts 1276680 thousand (Fig. 1).

The share of the special budgetary subsidy for keeping cows and the budgetary subsidy for growing young cattle is $21.4 \%$ and $13.4 \%$ respectively, which in monetary terms is 511836 thousand UAH and 320081 thousand UAH, respectively. All other payments account for less than $10 \%$ of total payments. Thus, the share of reimbursement of the value of purchased for further reproduction of breeding animals is $9 \%$ or 214572 thousand UAH, compensation for the value of objects financed by bank loans $-2.6 \%$ or UAH 62926 thousand. The lowest proportion of specific weight occupies a partial compensation of interest rates on bank loans $-0.2 \%$ or 3747 thousand UAH.

Experts believe that it is appropriate to control the size of government support in one entity trends: „Partial compensation of the cost of construction and reconstruction of livestock farms and complexes, milking parlors, enterprises on processing agricultural products in terms of cost, excluding VAT funded by bank loans” and „Partial reimbursement of the cost of construction and reconstruction of livestock farms and complexes, milking parlors, agricultural products processing enterprises" and must be substantially limited in order to prevent the use of state support of a narrow range of companies. 


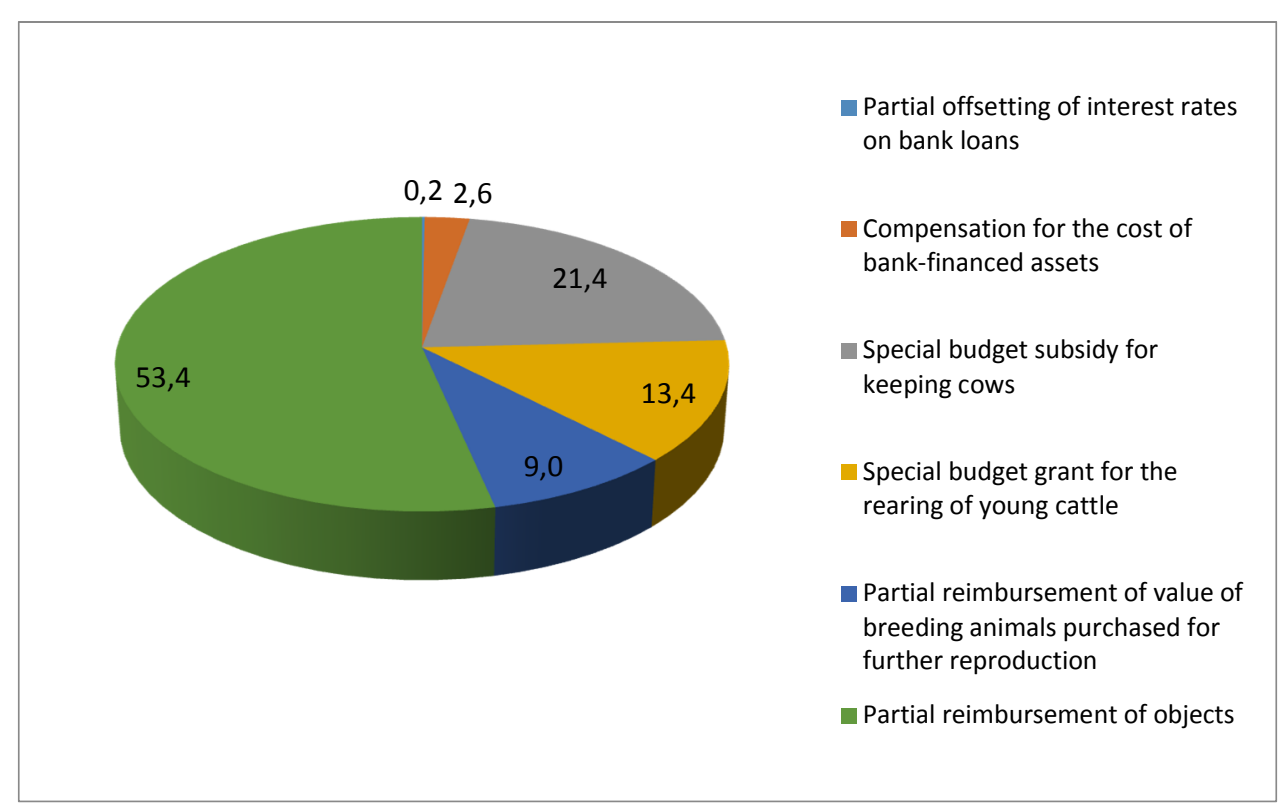

Fig. 1. Structure of expenditures on state support for livestock industries, 2018\%

Any areas of state support for the livestock sector should operate as much as possible without the involvement of state commissions, which in practice delay decisions on the granting of such state support and limit the involvement of the interested public.

Although state support for the livestock sector has been provided for since 2018, the pig industry itself has been left out of the state's attention, although pork producers, like other farmers, have suffered through the abolition of quasi-accumulation of VAT, and have also been systematically harmed by African losses swine fever and „black” pork imports. Thus, in 2020, the support of pork producers in the form of a budget subsidy for keeping pigs in the industry, at least at the rate of 2 UAH per kilogram of pork, must be provide Analysis of the state of use of budget funds under the program „State support for animal husbandry" in 2018 indicates that most of the funds were actually directed to partial reimbursement of the value of fixed assets - 1276679.9 thousand UAH, it should be noted that in this direction the largest amount of unused funds, namely -3320 thousand UAH. It should be noted that in the direction of the special budgetary subsidy for keeping cows, the amount of unused funds is quite significant and amounts to 3163.4 thousand UAH, but in percentage it is only $0.6 \%$ of the actually planned appropriations. In Artaud noted the program „Partial compensation interest rates on bank loans” and „Compensation cost of facilities financed by bank loans" in which the balance of unused funds 252.3 thousand UAH and 2079.3 thousand UAH, which is $6.7 \%$ and $3.3 \%$ of the funds actually directed to economic entities. The best use of money is traced to expenses such as partial reimbursement of the value purchased for further reproduction of breeding animals and a special budget grant for the rearing of young cattle. Thus, in 2018 , only $0.2 \%$ and $0.6 \%$ respectively were not used in these areas (Fig. 2). 


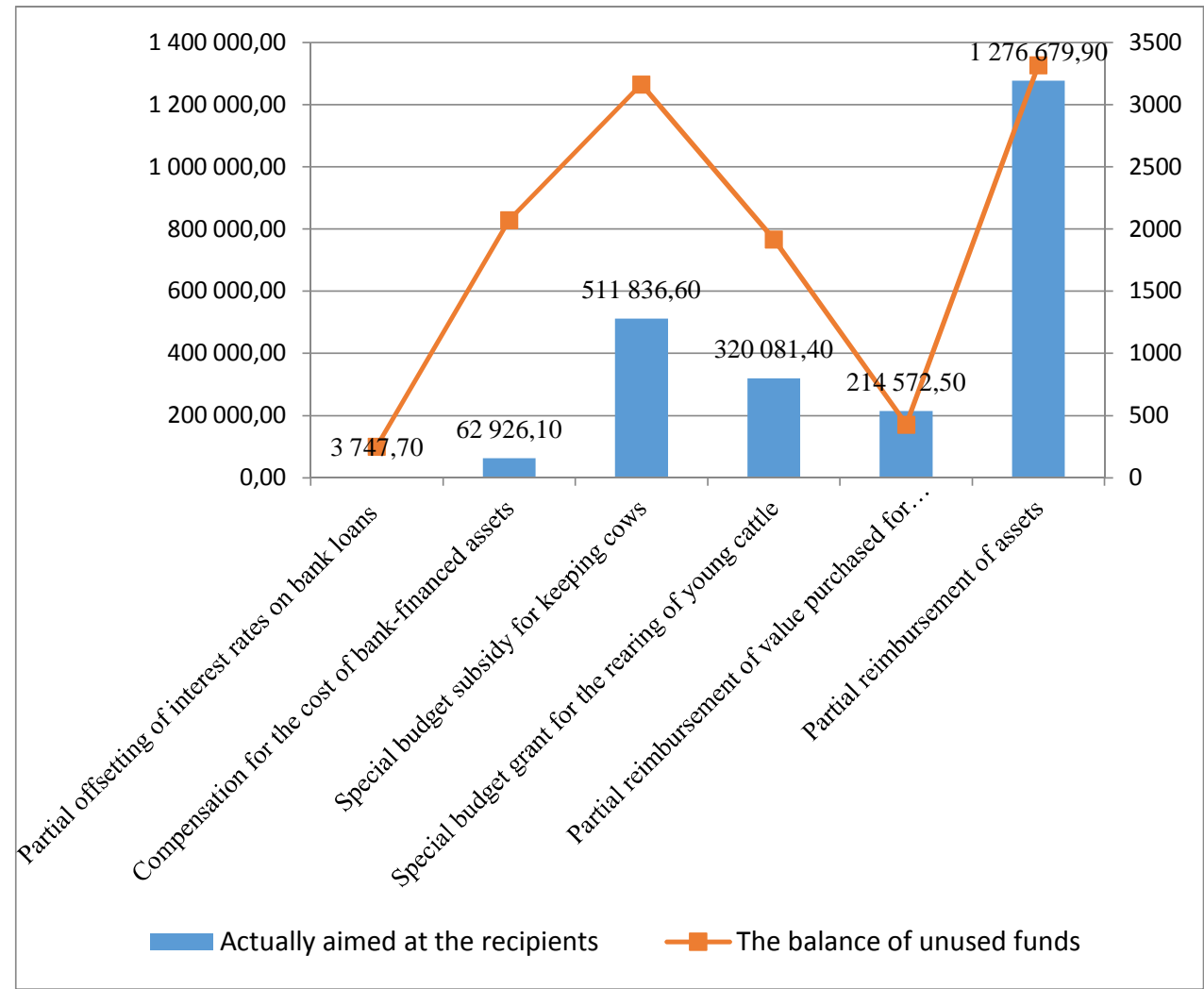

Fig. 2. State of use of budget funds under the program "State support for animal husbandry", 2018

Studies show that, unlike other government support programs, the repayment of funds by banks occurs in only two ways, namely partial compensation of interest rate on bank loans and partial compensation of the cost of construction and reconstruction of objects financed by bank loans.

Entities who have denominated in national currency in resident banks of Ukraine, who have signed a Memorandum of Understanding on a common basis for cooperation: short-term loans (except overdrafts) and credit lines reimbursement of production costs; medium- and long-term (non-revolving) loans to cover capital (investment) expenses. This applies only to loans raised to cover the costs incurred before activity in sheep, goat farming, beekeeping, animal farming, rabbit farming, sericulture and aquaculture.

The analysis of financial support for the development of the livestock sector in the context of banks shows that only $6.06 \%$ of the total state support to the agrarian sector was allocated to this program by the list of banks listed. Most of the funds, namely 63096 thousand UAH, were paid out by other banks that did not fit into the aforementioned aggregate, which is $98.4 \%$ of the total payments of the bank. PJSC „Ukrex-Simbank” makes the least money -179 thousand UAH (Fig. 3). 


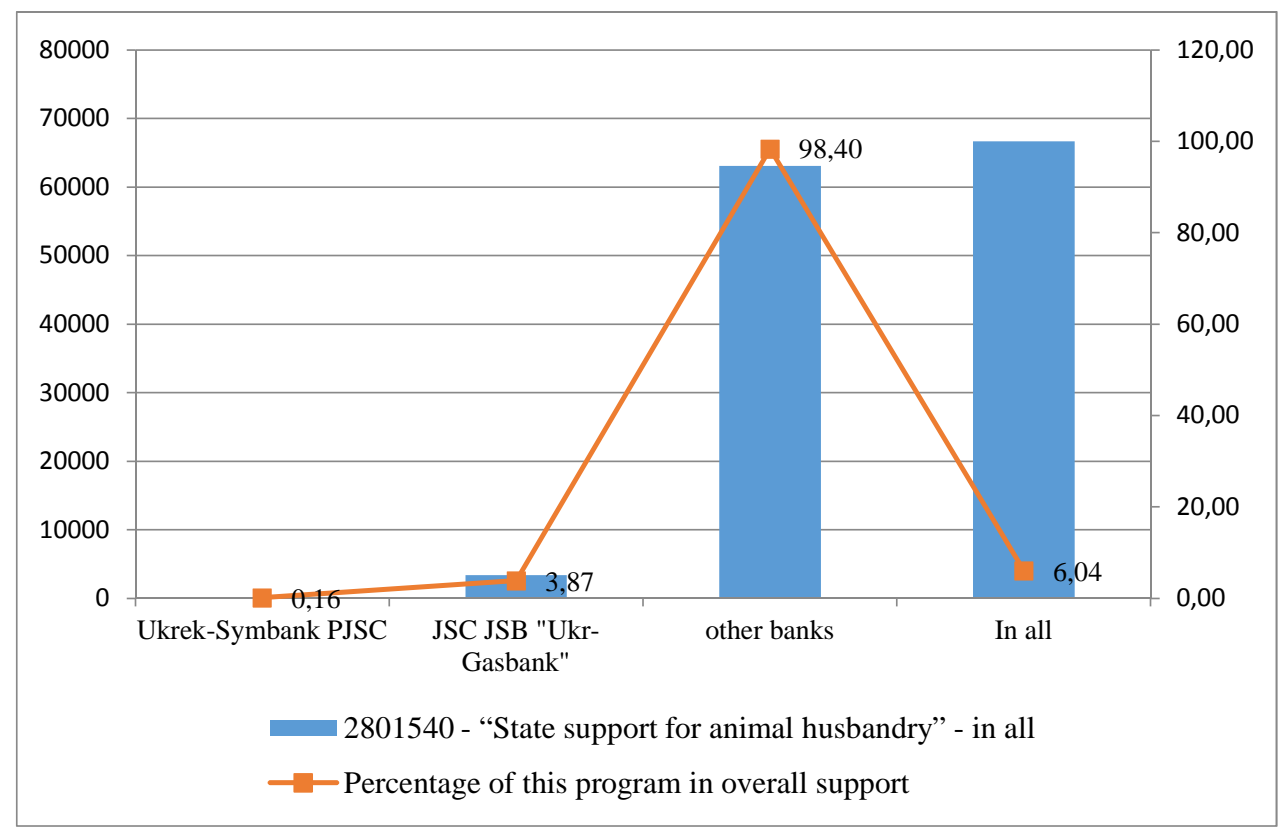

Fig. 3. Banking Support for Livestock Breeding, 2018

Higher growth rates of cattle in areas where agricultural holdings are stronger are not accidental and have a positive impact. In Ukraine, there are programs at the national and regional levels to support the purchase of dairy cattle (heifers) by enterprises for the replenishment of dairy herds. Consequently, the prospects of profitable sales of livestock farms in such regions are much higher, and the combination of several livestock support programs produces a certain synergistic effect.

The practice of modern state support for agrarians in Ukraine shows that there is an imperfect and non-transparent mechanism for selecting enterprises for compensation and subsidies, as a result of these types of support do not encourage owners to invest their own funds and invest in innovative technologies and equipment, which results in reduced production and cost increase its efficiency. Also, an under stat come now regulated pricing is the issue, as the situation in our country remains unchanged when the commodity is not to receives income, and while large companies are reselling profits.

The bulk of the funds invested in the State Budget for the support of the agroindustrial complex in 2018 (4 billion UAH or $28.3 \%$ of all resources) is directed to support livestock. In the second place in terms of financing - support for agriculture - in this direction allocated 1 billion UAH (7.1\% of the total).

To establish the mechanism of state support, as the experts point out, it is necessary to determine the right to receive a budget grant for the maintenance of cows and pigs not only to legal entities but also to natural persons-entrepreneurs who own cows and pigs, in order not to repeat the previous disadvantages of the direction of state support for maintenance cows, when only legal persons were entitled to it.

In addition, state support such as „Partial compensation for interest rates on bank loans raised to cover the costs associated with pursuing activities in the fields of sheep, goat, 
beekeeping, breeding, rabbit farming, silkworm and aquaculture (fisheries)" also include a very important support tool for producers - offsetting interest on working capital loans, and not just for sheep, goat, beekeeping, horse breeding, rabbit breeding, silkworm, aqua ultra, but also pig breeding and animal husbandry. State support „Partial compensation for the cost of construction and reconstruction of livestock farms and complexes, in part of costs financed without VAT from bank loans" and "Partial reimbursement of the cost of construction and reconstruction of livestock farms and complexes" must be added to the construction of enterprises infrastructure of livestock complexes (technological feed mills and workshops, feed mills) to increase localization of its own production of feed, which is currently insufficient.

\section{CONCLUSION}

Therefore, in the domestic market of livestock products is unstable, both in terms of prices and quantitative indicators. Its main trend is the decline in manufacturing output and constant these new variations.

In the current economic environment, producers are not able to independently increase production to the size necessary to meet the needs of the population for food. Therefore, effective state regulation of livestock is required. The volume of state financial support for agrarians in Ukraine is growing annually, but it is almost impossible to assess the role of subsidies in the development of the agricultural sector. Some argue in favor of this form of support for producers, on the other hand - subsidies and particularly opaque mechanisms of payment of the state budget are often turned into funds for supporting inefficient farms since they negate the incentives to improve production efficiency, in particular, lower cost, productivity, and product quality. Low returns on providing subsidies in Ukraine is also due to irregularities in the use of budget funds in the district and as a result, domestic manufacturers have unequal access to them. Large agricultural enterprises have significant advantages in this regard, being able to obtain in due time the necessary information and access to the structures dealing with the distribution of public financial resources. Given this, this industry is in need of substantial government support that would shape economic attractiveness of cattle production, and contribute to expanded reproduction of livestock. All of this utilities can reduce the payback period of investment in the sector.

\section{REFERENCES}

Demchak, R.E. (2015). Conceptual principles of decentralization of state regulation of socioeconomic development. Proceedings of the National University of the State Tax Service of Ukraine, № 1.

Galitsky, O.M. (2016). State regulation of agricultural production of the national economy in the context of European integration. Bulletin of Sumy National Agrarian University series "Economics and Management", No. 8 (69).

Haydutsky, P.I. (2017). State support as a factor in regulating the domestic agricultural machinery market in Ukraine. Bulletin of Kharkiv National Agrarian University B.B. Dokuchaev, №2.

Kushnir, S.O. (2017). State support of agroindustrial complex. „Ukrainian Journal of Applied Economics", Vol. 2, Issue 1. 
Lupenko, Yu.O., Tulush, L.D. (2016). Taxation of agriculture in the conditions of transformation of special tax regimes. Economics of AIC, №. 1.

Mesel-Veselyak, M.Ya., Fedorov, M.M. (2016). Strategic directions of development of the agrarian sector of the economy of Ukraine. „APK economy”, № 6.

Panukhnik, O.V. (2017). State support for agrarian subjects. „Actual problems of an innovative economy”, № 1 .

Resolution of the Cabinet of Ministers of Ukraine (2018). „On Approving the Procedure of Using the Funds Provided in the State Budget to Support Livestock, Storage and Processing of Agricultural Products, Aquaculture (Fisheries)" of February 7, No. 107.

Synyavina, Y.V. (2015). Economic evaluation of the state of livestock and support its development . Economic analysis. Volume 19. No. 3. P.134

Tulush, L.D. (2017). Quasi-accumulation of VAT as a tool to stimulate the development of priority salt velocity household activities. Proceedings of Uman National University of Horticulture, № 91.

Ulyanchenko, Yu.O. (2013). Competitiveness of the agrarian sector of the economy: mechanisms of state regulation : [monograph ]. X.: Publication of the Association of Doctors of Sciences in Public Administration, 368 p.

Yemtsev, V. (2012). Livestock industry in Ukraine: current state, problems and development prospects. „Livestock breeding in Ukraine”, № 12.

DOI: 10.7862/rz.2020.mmr.10

The text was submitted to the editorial office: March 2020.

The text was accepted for publication: March 2020. 
